GEOGRAFICKÝ ČASOPIS / GEOGRAPHICAL JOURNAL 71 (2019) 3, 263-281

DOI: https://doi.org/10.31577/geogrcas.2019.71.3.14

\title{
SPATIAL MOBILITY AND CURRENT TRAVEL BEHAVIOUR IN THE METROPOLITAN HINTERLAND
}

\author{
Ondřej Pešek*, Stanislav Kraft** \\ * Ministry of Regional Development of the Czech Republic, Staroměstské náměstí 6, 11015 Prague, \\ Czech Republic, Ondrej.Pesek@mmr.cz \\ ** University of South Bohemia, Department of Geography, Jeronýmova 10, 37115 České Budějovice, \\ Czech Republic, kraft@pf.jcu.cz
}

\begin{abstract}
Spatial mobility and current travel behaviour in the metropolitan hinterland
This article deals with current changes in mobility patterns and travel behaviour in the Czech Republic. The study is focused on the metropolitan hinterland of Prague. It is based on a detailed research of recent mobility patterns and transport behaviour in the administrative district of Benešov, which is located near Prague. This region was strongly influenced by the transformation of the spatial structure of the settlement system in the Czech Republic. As a result, there is a strong orientation on commuting to Prague. The study uses the database from last two population censuses to analyze the main spatial patterns of commuting to work and to schools in the district of Benešov between 2001 and 2011. The second part analyses current trends in transport behaviour of commuters based on a questionnaire survey. The study brings a few interesting results about the changing structure of spatial mobility and preferences of various transport modes as a part of complex transport behaviour.
\end{abstract}

Key words: commuting to work, spatial mobility, transport behaviour, metropolitan areas, transport mode choice, district of Benešov in Czechia

\section{INTRODUCTION}

It is an undeniable fact that the fall of the Iron Curtain and the transformation processes that followed in many post-socialist countries were reflected in many social, economic, political and cultural aspects. These changes further lead to a series of spatial causes and impacts, which were also largely reflected in the different patterns of the spatial organisation of a society. This mostly concerns the quite large dynamics in settlement systems where post-industrial processes started to gradually manifest in relation to the post-socialist transformation. According to Hampl (2005), the joint features of the transformation from the industrial to postindustrial organisation of a society can also be characterised, among others, by a sudden increase in individual mobility, intensification of information and communication technologies, spatial de-concentration of functions (housing, services and job opportunities), development of metropolitan areas, creating complex spatial patterns of relations in the settlement system, and last, but not least, by reducing the polarisation between the core and the hinterland (e.g. Sýkora and Mulíček 2009). Therefore, we can assume that in addition to the massive development of suburbanisation processes, integration processes take place at the higher hierarchical levels. This research has primarily focused on the complex processes of transformation of the settlement systems (e.g. Hampl 2005) or the related partial transformation processes (Špačková et al. 2011, Sýkora and Bouzarovski 2012, Novotný 2016 etc.). Less attention has been paid to changes in spatial mobility patterns and the related transport behaviour that are the direct consequence and also the initiator of the aforementioned changes. The statement that the aforementioned processes can be 
monitored through changes in the spatial patterns of individual mobility therefore applies. In this context, human mobility is one of the best indicators of the aforementioned changes with an extraordinarily high information capability.

The article deals with a detailed empirical study of changes in the spatial patterns of mobility and transport behaviour within a metropolitan area, using the Benešov administrative micro-region (hereinafter referred as AMR) as an example. The Benešov AMR is located in the hinterland of Prague and it has been significantly influenced by the development of the metropolitan functions of Prague in recent years, including the penetration of suburbanisation processes and related functions (e.g. Ouředníček 2003). Therefore, we believe that this micro-regional study declares a number of general processes related to the changes in the spatial mobility of the inhabitants living in the hinterland of large metropolitan centres in post-socialist countries (similarly Novák and Sýkora 2007 and Borén and Gentile 2007). The study uses information from an extensive database of commuting flows from 2001 and 2011. The study strives to point out the main changes and trends in commuting to work and to school in recent years within the specific environment of metropolitan regions. We study especially the effect of distance and travel time. as the crucial influencing factors of spatial mobility and travel behaviour. The second part then includes an evaluation of a questionnaire survey that aims at assessing the current tendency in travel behaviour. The individual reasons of respondents for using different transport modes and their transport preferences are also an important topic. With regard to the distance of the monitored region from Prague, we can particularly assume that people living in the more remote parts of the district are forced to travel for much longer periods, to spend much more money, and that they are more dependent on cars. One of the other objectives of the study includes the assessment of the potential change in the workplace (usually localised in Prague) with regard to the unfavourably perceived mobility of the respondents.

The article can be used at the level of basic and applied research in many ways. With regard to the general trends in the development of spatial mobility in postsocialist countries, it is presumable that the results of the study will contribute to understanding the current trends in changes in commuting and transport behaviour of inhabitants in metropolitan areas. At the same time, the article points out a number of other aspects related to daily mobility and transport behaviour of inhabitants, including the questions of the future long-term development of mobility. The results of the study are thus not only relevant for geographers, but they can also be used by transport planners, sociologists, economist and others.

\section{MOBILITY AND TRANSPORT BEHAVIOUR IN POST-SOCIALIST SOCIETIES}

As stated above, the aforementioned changes in mobility and travel behaviour in the monitored region are substantially influenced by the general changes in the spatial organisation of the post-socialist society (see e.g. the studies by Pucher 1990, Grdzelishvili and Sathre 2011, Popov 2012 or Burrell and Hörschelmann 2014). Thus, the following text mentions the main concepts of the change in the mobility and transport behaviour in post-socialist countries. Mobility is one of the basic concepts of transport geography. It is understood as the ease of movement in space (see e.g. Hanson 2004). Geographical research accentuates mobility related 
to the spatial movement of people. Considering the fact that an individual cannot find everything that they need for their life in their immediate surroundings, the individual is forced to move in space. Therefore, mobility is the consequence of satisfying the basic essentials of life and wishes. It is assigned an extraordinary significance as it allows the use of space effectively (Adey 2009). However, the fact that human mobility is not only continuously intensifying, but that its spatial organisation is changing at the same time, is also crucial. In this context, we can state that spatial mobility patterns carry "coded" general trends of the spatial organisation (e.g. Hampl 2005). This crucial property of mobility has been confirmed, for example, by the well-known Zelinsky hypothesis of mobility transition (Zelinsky 1971) that understands mobility as the crucial factor of the modernisation process. By the way, this model declares that the main original forms of spatial mobility (migration) change into circulating movements (commuting, high-speed transport, information and communication technology). And it is the circulating movements of inhabitants that have been given a lot of attention in geography in recent decades. Contemporary society is often called a hypermobile society, with all its positive and negative consequences (Cohen and Gössling 2015).

A specific development of spatial mobility can be seen in the former socialist countries of Central and Eastern Europe. The processes of mobility in those countries were strongly influenced by artificial interventions in the entire transport system (Popov 2012). We can state, with some simplification, that the centrally planned economy system contained a strongly regulated system of centrally planned mobility. Burrell and Hörschelmann (2014) also reached similar conclusions based on the empirical analyses from various areas of the post-socialist system. The specific manifestations of centrally planned mobility were, in particular, the lower level of automobilisation (socialist states traditionally used to show significantly lower automobilisation than capitalistic states), limited investments into transport infrastructure, significant dominance of public transportation, low intramodal and intermodal competition on the transport market, etc. (e.g. Pucher 1999, Horňák and Pšenka 2013, Tomeš et al. 2014, Michniak 2015 etc.). And those aspects created the initial position for the transformation of transport systems in the former socialist countries in Central Europe. The common feature of this transformation was the relatively fast development of some branches of the transport industry (namely car transport). The main "external" determining factors of the changes include changes in the size structure of companies, development of suburbanisation processes, and the development of new forms of travel and leisure activities. These changes then led to the increased intensity of commuting to work and to school (Kraft and Květoň 2015). Even though the processes took place with varied intensity and at various stages in the post-socialist countries, they form the basic external framework of the transformation of their transport systems.

The post-socialist transformation processes are also related to changes in the spatial aspects of transport behaviour (see e.g. Pucher and Buehler 2005, Krisjane et al. 2012 or Silm et al. 2013). Transport behaviour is a complex category of human behaviour in space and use of the individual transport modes. However, the available data only allows the evaluation of some aspects of transport behaviour. As an example, there are available databases on the automobilisation of the individual states, which clearly imply that there has been a rapid growth in the number of registered passenger vehicles in all former socialist countries (e.g. Komornicki 2008). The growth in the number of passenger vehicles was then accompanied by a 
logical decrease in the interest for public transport, which was manifested in its lower intensity and effectivity (Marada et al. 2010). Specifically, the reduction in public transport affected a number of suburban regions which had a significant effect on the transport behaviour of the inhabitants. Poland shows the highest dynamics in the growth of individual automobilisation after 1990 out of the post-socialist states in Central Europe. It is a result of the relatively high undersizing of individual transport in combination with the lower intensity of public transport that was already substantially reduced during the 1990s (namely railway transport Taczanowski 2012). The modal shift to cars is thus one of the most significant attributes of the changes in the transport behaviour in post-socialist countries. The development of transport behaviour during the transformation period is also interesting. Marada and Květoň (2016) declare, using the changes in transport behaviour in the Czech Republic as an example, that the passenger car quickly became the most frequently used transport mode in the commute to work. Its strong dominance was obvious as early as in 2001, however, its significance more than doubled by 2011 .

The aforementioned general mechanisms and process of the transformation of mobility and transport behaviour can also be very well identified in the specific environment of the Czech Republic. Kraft and Prener (2014) unambiguously confirm the relatively high spatial differentiation in the transport behaviour in relation to the post-socialist transformation after 1989. The changes in the automobilisation of the individual regions (the number of registered passenger cars per 1,000 inhabitants) led to the convergence of the state. In 2007, for example, there were substantial differences between the highly automobilised western part (mostly large cities in Bohemia) and the less automobilised eastern part of the Czech Republic (namely Moravia). This spatial pattern remained the same until 2014; however, the polarity between Bohemia and Moravia was significantly reduced. The authors contribute this situation to the gradual penetration of changes in transport behaviour and the growth of the significance of the passenger car in regions that used to be traditionally oriented to public transport. The improved economic position of the regions where inhabitants can afford one or more passenger cars plays its role. In spite of that, the highest level of automobilisation is more typical of rural and suburban areas of the Czech Republic than for cities (Kraft and Prener 2014). This spatial differentiation is also related to other aspects of transport behaviour, namely the use of the individual transport modes when commuting to work. The highest use of passenger cars is typical for regions of the inner periphery, i.e., those inland regions on the borders of higher administrative regions and more distant from the main settlement centres (Musil and Müller 2008). It is where the reduction of public transport and shifting to local administrative/work centres, and increased demand for traveling to the more distant regions (cities) with more job opportunities and higher wages has a negative effect. The development in the changes in transport behaviour in the hinterland of large metropolitan centres (specifically the broader hinterland of Prague and Brno) in the period of the last two population censuses in 2001 and 2011 is also interesting. While in 2001, these hinterlands were strongly oriented to the use of passenger cars (usually the suburban hinterland of large cities with wealthier inhabitants), in 2011 those were the most significant areas in the use of public transport. Many authors believe that this change in transport behaviour was mostly caused by the problems with using cars (such as parking in 
cities) and the recent revival of public transport in the hinterland of large cities and its incorporation into the integrated transport systems (e.g. Št'astná et al. 2015). Those more general findings became the basic starting point of the submitted study that maps the current transport behaviour in the hinterland of Prague in greater detail, using quantitative and qualitative research methods.

\section{DATA AND METHODS}

We worked with two basic data sources in our study. The first database is formed by the results of the Population Census of 2001 and 2011 that was used to determine commuting to work and to school. During the inter-census period, the data census methodology was modified: in 2001, commuting was monitored with regard to the permanent residence, whereas in 2011 the place of usual residence was monitored. Also, a lot of data was lost in the 2011 census due to the lower willingness of inhabitants to record information. However, Hampl a Marada (2015) argue that the loss of data and the reduction in the database can be seen all over the Czech Republic and that the data is still relevant when monitoring commuting, in spite of the reduction in the absolute values. Tonev (2013) also argues in a similar way. This type of data was used in the analysis of the major changes in the spatial mobility of inhabitants in the monitored region between 2001 and 2011 through the regions where the inhabitants commute to work and to school. The delimitated commuting regions are based on the existence of the strongest commuting flow, by assigning the individual municipalities to the centres. The combination of work and school commuting is used as a regionalising criterion. However, unlike in previous studies, this study also works with non-daily commutes at the micro-regional level. The first reason for this step is that the study aims to assess the influence of the hierarchically superior centre of Prague and, according to Hampl (2005), the nondaily commuting is important when determining the catchment area at higher hierarchical levels. The second reason is the expansion of the database (considering the aforementioned critique of the data on commuting) and the relevance of such data for the fulfilment of the objectives of the study and for defining the regions where people commute. In 2011, the total number of people commuting on a non-daily basis from Benešov AMR was 3,423 commuters, of which $42.5 \%$ commuted to Prague and $24.3 \%$ within the district. Thus, most of the non-daily commute flows were within the primarily monitored area and other non-daily commute flows had minimum effect on the resulting regions where people commute. We study the effect of distance and travel time on commuting regarding the basic hypothesis of spreading of commuting to Prague from far areas of the monitored AMR.

The second basic source of data includes data acquired from a questionnaire survey that was performed in the monitored region in November and December 2015 (Pešek 2015). The survey was distributed in an electronic form via e-mail and social networks, and it was aimed at people living in the Benešov AMR who commute to work in Prague. The survey was designed to capture various aspects of the mobility and transport behaviour of the respondents, such as the transport mode choice, time of commuting, transport costs, etc. A secondary objective was to record the perception of the commuting and time spent commuting. A total of 236 respondents from the district of Benešov working in Prague, from 44 different municipalities within the district, participated in the questionnaire survey. Most of the 
respondents were from the important centers with job opportunities in the Benešov AMR (Benešov - 31.7\%, Vlašim - 11.4\%, Votice - 6\% and Týnec nad Sázavou $4.5 \%$ ). The rest of the respondents were from smaller municipalities, especially from the northern part of Benešov AMR, so close to Prague. The total number of respondents corresponds with approx. $4.6 \%$ of the people commuting to work in the capital city from the Benešov AMR according to the 2011 Census results. The gender distribution of the sample was balanced (50.8\% men and $49.2 \%$ women). The average age of the respondents was 29.6 years and the largest age group was respondents under $24(32.2 \%)$, followed with the age groups of $24-29(28.4 \%$ respondents), $30-39(27.5 \%), 40-49(7.6 \%)$ and $50-59(4.2 \%)$. The youngest age group dominated the sample of the respondents to the questionnaire survey. When compared with the results of the 2011 Census, there was lower representation of people over 40 in the respondent sample. These age disproportions were caused by the method of distributing the questionnaire, and also by the fact that working students are not considered economically active inhabitants for the purpose of the statistical census survey, whereas this group was intentionally included in the questionnaire survey. This fact thus shifted the age distribution of the respondents to the lower age categories. The relevance of the sample was confirmed by the $25-39$ age group, where $55.9 \%$ of respondents belong, which correspond approximately with the results of the 2011 Census, where this age group represented $54.8 \%$ of commuters from the district of Benešov to Prague. With regard to education, the largest group among the respondents were university graduates $(47.9 \%)$ and high school graduates $(47.0 \%)$. When compared with the results of the 2011 Census, there was a higher proportion of university graduates and a similar proportion high school graduates (2011 Census: $31,5 \%$ university graduates and 51,7\% high school graduates). This is probably due to the method of spreading the questionnaire. The information from the questionnaire survey was processed using descriptive statistics methods.

\section{COMMUTING PATTERNS AND THEIR RECENT CHANGES}

Commuting patterns are very good indicators of the spatial organization of society. Table 1 provides information on the population size and the numbers of municipalities in the corresponding commuting regions in the analysed years and reflects both the changes in the borders of the commuting regions and the population development of the municipalities in $2001-2011$. There is a significant weakening of the hinterland of the micro-regional centre of Benešov by more than ten thousand inhabitants and 18 municipalities (Tab. 1). The orientation of these municipalities shifted to Prague in 2011. The micro-regional significance of Prague within the monitored area grew by almost eighteen thousand inhabitants within the monitored area and its sphere of action expanded by 26 municipalities in total. In addition to the influence on the northern part of the administrative micro-region of Benešov, the city of Prague also had a direct influence on the southeast part of the administrative micro-region of Vlašim - Dolní Kralovice and its surroundings with a population of about two and a half thousand people in 2011. The reason is the increased commute of the inhabitants to Prague using the D1 highway, (see e.g. Hudeček 2010). The total population increase of the district of Benešov by almost five thousand inhabitants was mostly recorded in the municipalities within the micro- 
regional sphere of action of Prague, in the northern part of the Benešov region, i.e., in an area with convenient accessibility to Prague where intense suburbanisation processes take place (Ouředníček 2007).

Tab. 1. Commuting regions in the district of Benešov in 2001 and 2011

\begin{tabular}{lrrrr}
\hline \multirow{2}{*}{ Name of the region } & \multicolumn{2}{c}{ Population } & \multicolumn{2}{c}{ Number of municipalities } \\
\cline { 2 - 5 } & \multicolumn{1}{c}{2011} & 2001 & 2011 & 2001 \\
\hline Benešov & 40,588 & 50,768 & & 47 \\
(hinterland) & $(24,324)$ & $(34,445)$ & 29 & \\
Vlašim & 23,261 & 23,751 & & 36 \\
(hinterland) & $(11,538)$ & $(11,481)$ & 38 & 17 \\
Prague & 30,072 & 12,289 & 43 & 1 \\
Tábor & 974 & 1,011 & 3 & 10 \\
Sedlčany & 564 & 481 & 1 & 114 \\
Havlíčkův Brod & 0 & 2,325 & 0 & 114 \\
Benešov AMR & 95,459 & 90,625 & & 3 \\
\hline
\end{tabular}

Source: CZSO (2002 and 2013), Pešek (2015), modified.

In 2001, 5,483 economically active inhabitants commuted from the district of Benešov to work in Prague. In 2011, there were 5,082 commuters. However, as mentioned above, this absolute data cannot be compared due to the loss of a significant part of the commute flows in 2011. Hampl and Marada (2015) stated that the loss of commute flows is all over the country and it is only possible to compare the relative values between the individual flows. In $2001,17.1 \%$ of all the people in the Benešov AMR commuting to work went to Prague. The number went up to $25.8 \%$ in 2011. The increase in the Prague influence on the proportion of the total statistically recorded work-related commutes within the district is 8.7 of the percentage point during ten years. This was an increase of 13.2 percentage points in the municipalities of the Prague micro-region (within the district of Benešov). It was 9.6 percentage points in the municipalities of the commuting micro-region of Benešov and 3.1 percentage points in the municipalities of the commuting microregion of Vlašim. However, we need to consider that the real (statistically unrecorded) influence of Prague is much more significant and that the increase in its influence during the inter-census period is much more considerable (e.g. Kraft and Marada 2017). Figs. 1 and 2 show the commuting regions in Benešov AMR. 


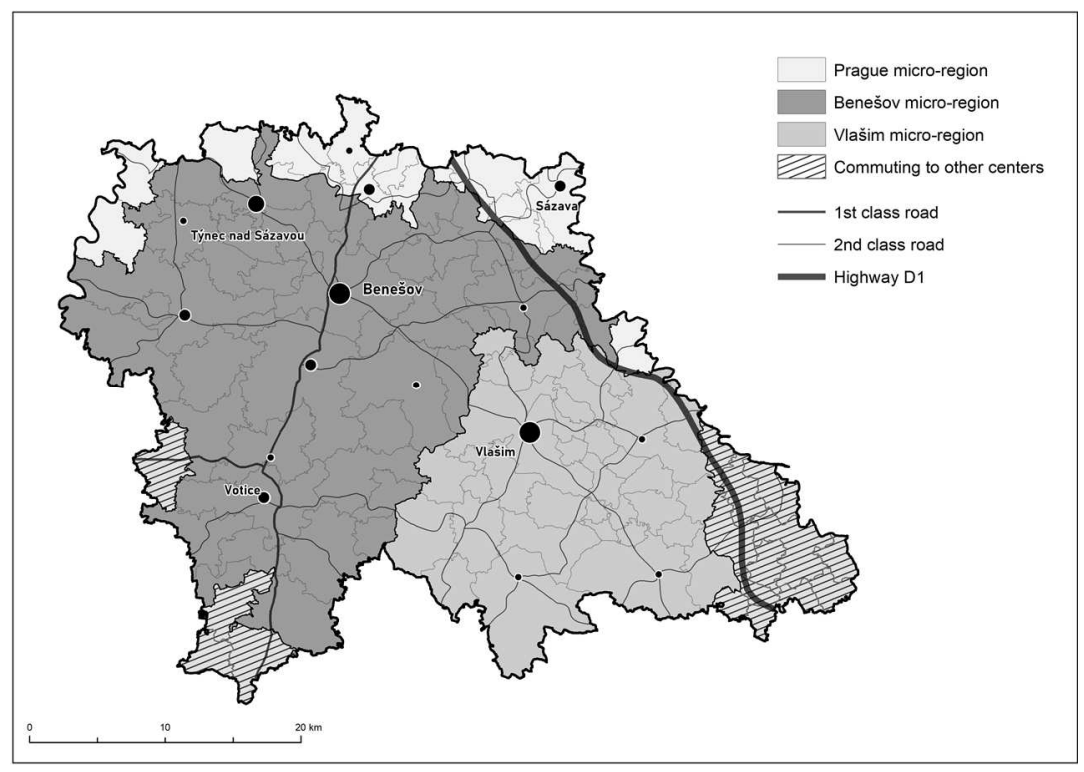

Fig. 1. Commuting regions in Benešov AMR in 2001 Source: CZSO (2002), Pešek (2015), modified.

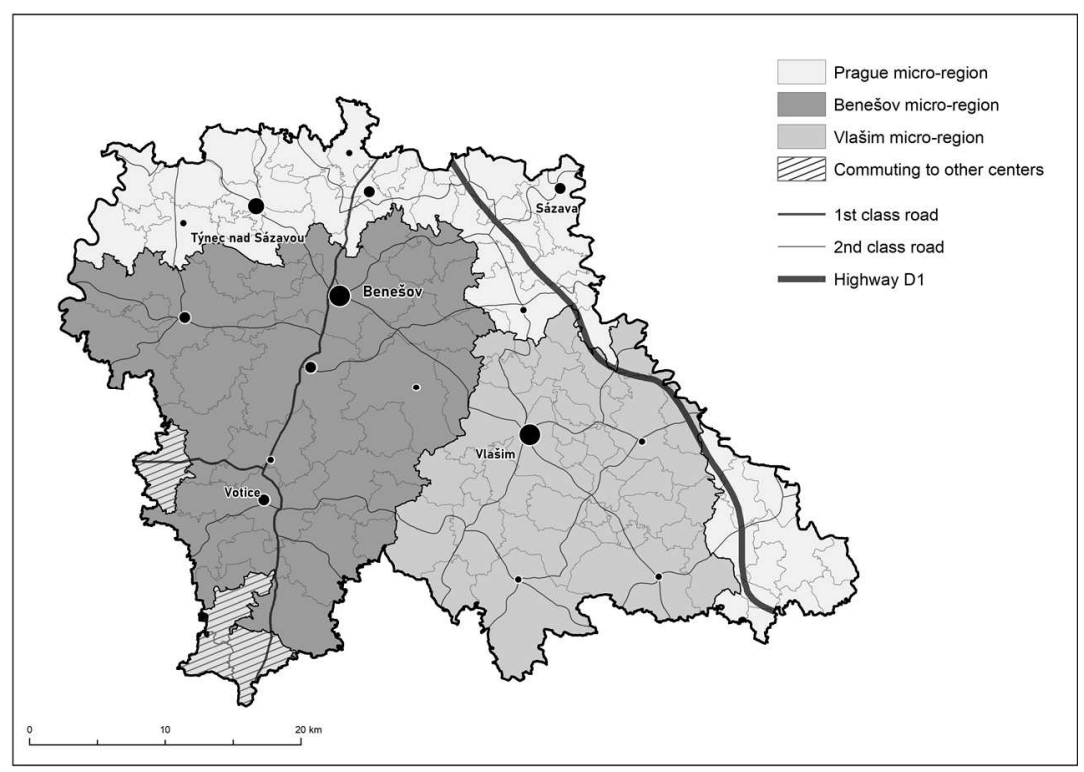

Fig. 2. Commuting regions in Benešov AMR in 2011

Source: CZSO (2013), Pešek (2015), modified.

Generally, we can confirm the growing importance of commuting to Prague between 2001 and 2011. The effect of the Prague labour market can be also measured by the share of the population commuting to Prague from all outbound peo- 
ple. The growing influence of the Prague labour market is namely evident in the whole AMR (not only in the commuting micro-region of Prague). Thus, we paid our attention to this issue. Figs. 3 and 4 show the influence of Prague in the Benešov AMR. It is evident that Prague influences the regional labour market very strongly in the Benešov AMR. Between 2001 and 2011 spread Prague its influence within the whole AMR. This is caused mainly by its growing importance in the whole labour market in the Czech Republic. The strengthening of its position is influenced by the highest salaries and the offer of different job positions. These processes were accompanied by the weakening of job positions on the local labour market within the Benešov AMR (often by the collapse of traditional local industrial companies). The second factor is then the suburbanization process which caused the migration of people from Prague to its hinterland. The change of residence is often not followed by the change of workplace. As a result, residential suburbanization is mainly followed by the redistribution of people but only partly by the redistribution of workplaces (see e.g. Sýkora and Mulíček 2009).

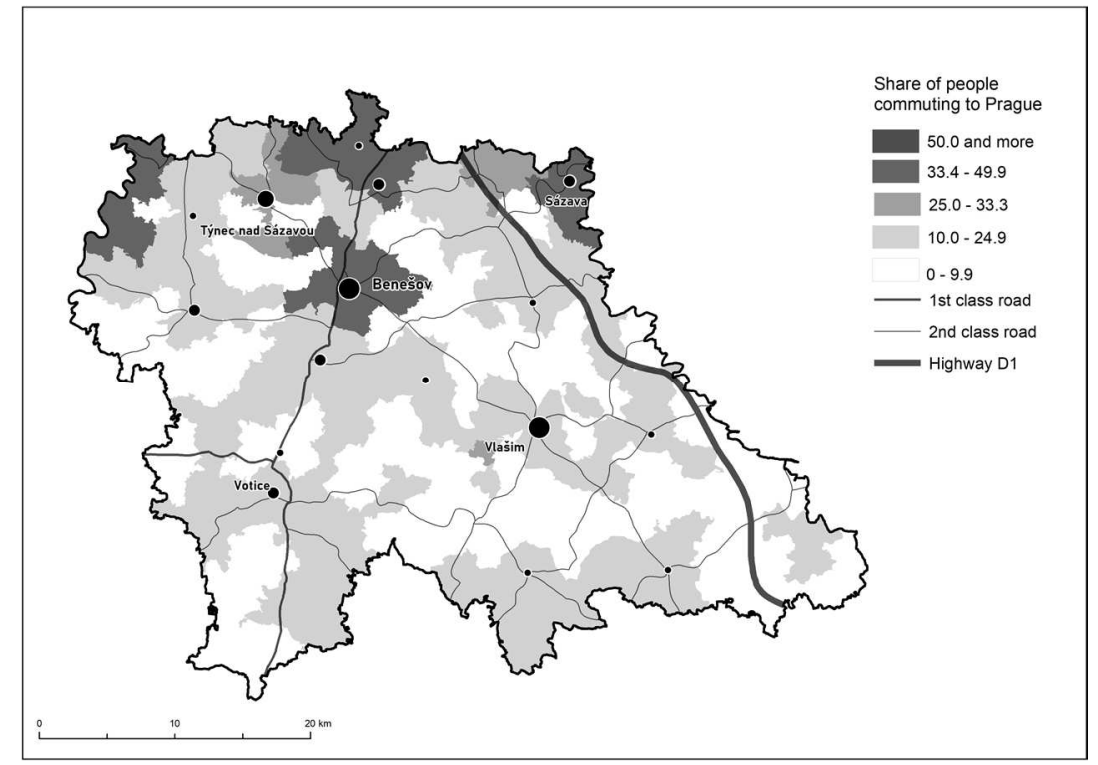

Fig. 3. The regional influence of Prague in Benešov AMR in 2001 Source: CZSO (2002), own calculations.

The above-mentioned analyses show a general growth of the force of Prague in the studied area. Generally, we can confirm that areas close to Prague are more dependent on the Prague labour market than more distant areas. This issue is in geographical studies known as a distance decay (see e.g. Fotheringham 1981 or Halás et al. 2014). There are of course some differentiation factors destroying this general formula. Transport infrastructure generating better/worse transport accessibility, the existence of local job opportunities and other factors can be ranked as the most important. Figs. 5 and 6 show the growing dependency of municipalities within the Benešov AMR on Prague according to the distance from Prague. It is evident that the dependency grew rapidly from 2001 to 2011. As a result, people commute to Prague from distant areas. This is connected with the growing time 
necessary to commuting, probably higher transport costs and many others negative factors (see e.g. Schwanen and Dijst 2002).

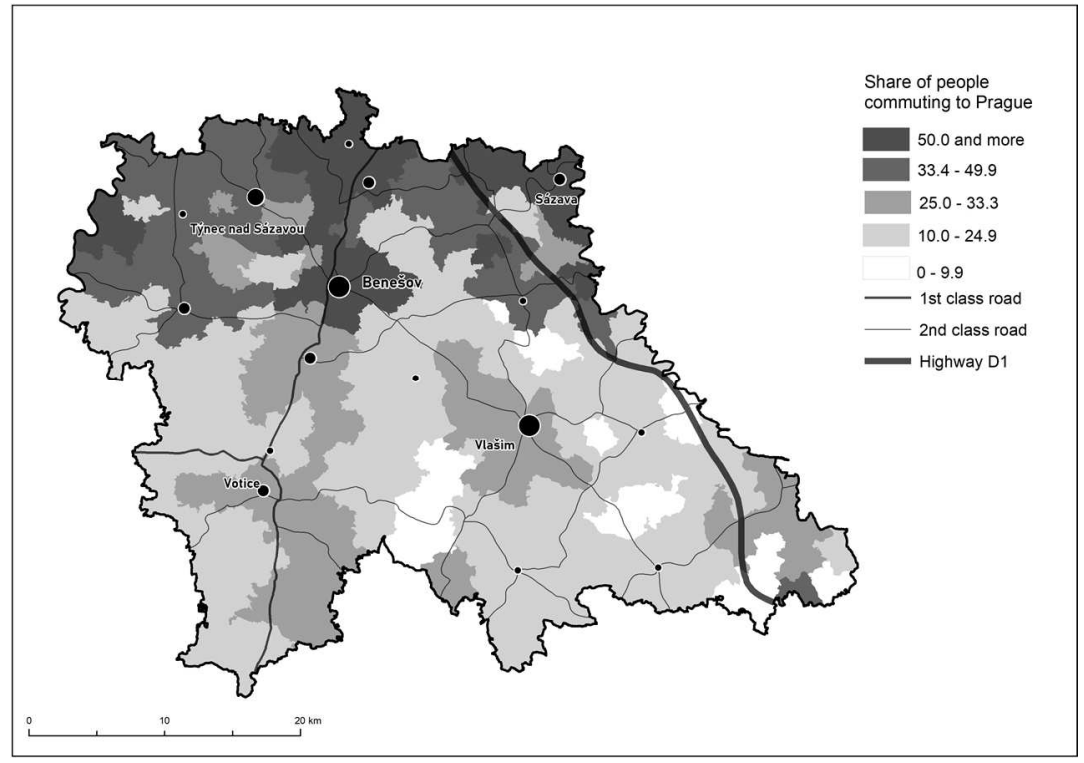

Fig. 4. The regional influence of Prague in Benešov AMR in 2011

Source: CZSO (2013), own calculations.

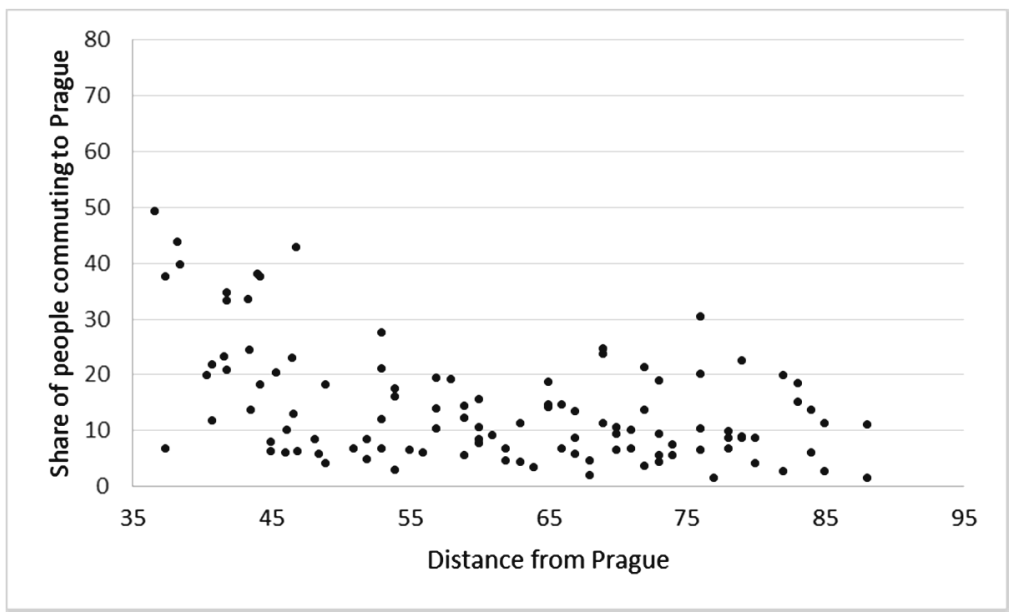

Fig. 5. The share of people commuting to Prague according to distance in 2001 Source: CZSO (2002), own calculations. 


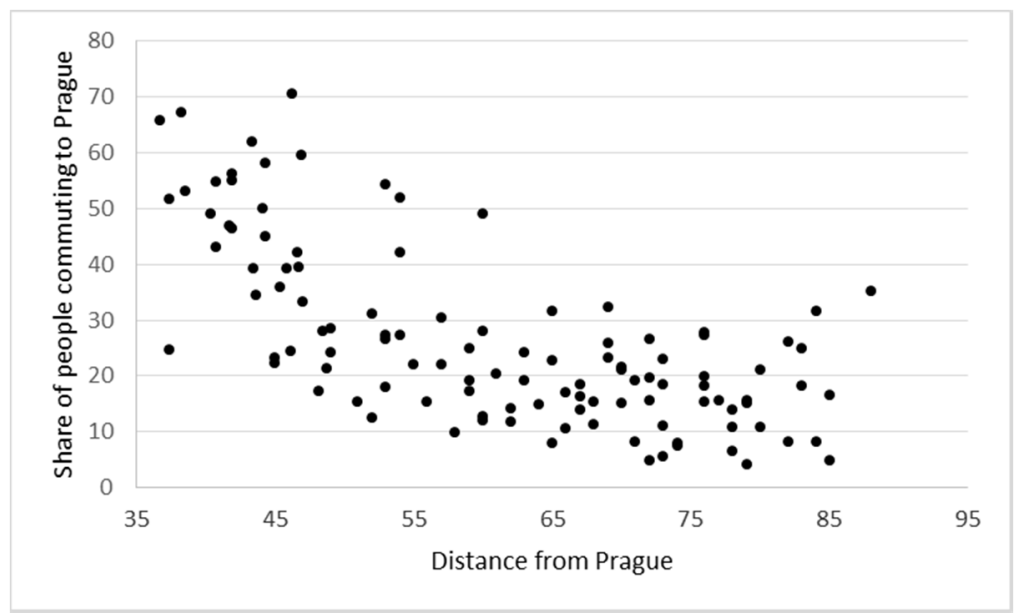

Fig. 6. The share of people commuting to Prague according to distance in 2011 Source: CZSO (2013), own calculations.

\section{TRANSPORT BEHAVIOUR OF COMMUTERS IN THE METROPOLITAN HINTERLAND}

The second part of the study is dedicated to the selected aspects of transport behaviour of commuters. The selected transport mode plays a crucial role in commuting. Almost three-fifths of the respondents (59.1\%) stated that they use a passenger car for commuting, while $31.8 \%$ of the respondents stated that they commute alone, as a driver without any passengers. Only $15.2 \%$ of the respondents use carpool and $12.1 \%$ of the respondents use a passenger car in combination with public transport. More then two-fifths of the respondents $(40.9 \%)$ only use public transport $(21.2 \%$ train, $12.6 \%$ bus and $5.6 \%$ bus and train, Fig. 7$)$. There were significant differences with regard to the gender in the selection of the transport modes. There are less women driving alone without any passengers (by $23.6 \%$ less than men) and more women who carpool (by 10.6\% more than men) and who also use a bus more frequently (by $8 \%$ more than men). The study also examined the determining factors in the selection of transport modes for the commuters, and the respondents chose a combination of two aspects that affect them the most out of four aspects (price, speed, flexibility and comfort). The drivers without passengers preferred mostly speed $(87.3 \%)$, in combination with flexibility $(54.0 \%)$, comfort $(19.0 \%)$ and price $(14.3 \%)$. The other daily commuters mostly preferred speed and price. For example, the carpooling commuters preferred speed $(86.7 \%)$, but more in combination with price $(36.7 \%)$ and then flexibility $(30.0 \%)$ and comfort $(20.0 \%)$. The commuters using a bus preferred speed $(84.0 \%)$, price $(56.0 \%)$ and flexibility (36.0\%). The commuters using a train preferred speed and price: $73.8 \%$ commuters stated one of those factors and $46.7 \%$ stated the combination. The commuters using combined transport more often stated flexibility and comfort than the commuters only using public transport. The cost is a determining factor when selecting the transport mode. Almost one-half of the respondents $(45.8 \%)$ stated price as one of the two aspects when selecting the means of transport. The average monthly costs of transport are CZK 3,105 (EUR 121) and when all the analysed 
means of transport were compared, the most expensive one is the passenger car, followed by the bus, with the train being the most economical means of transport. Furthermore, the study implied that $59.6 \%$ of the respondents used Prague public transport when commuting to work and out of the $40.4 \%$ of the respondents who do not use Prague public transport, $82.6 \%$ are people who use their own car to commute to work. Almost all commuters (96\%) use a bus to get to Prague also use the Prague public transport, whereas it is only $81 \%$ of commuters who use trains. This difference is given by the position of the train station in the city centre where people can walk, and the position of the bus terminals in the southern outskirts of Prague.

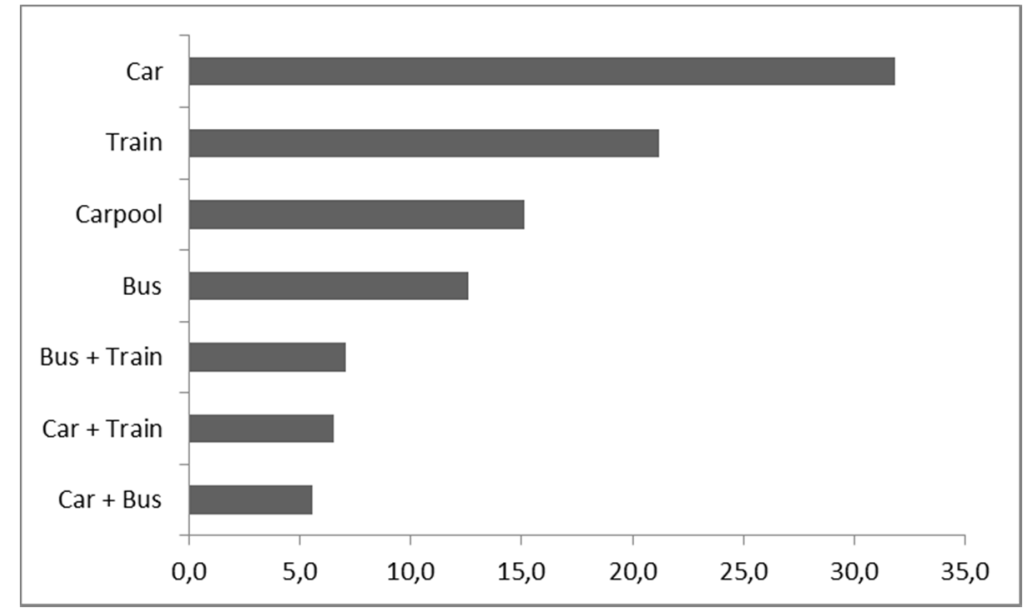

Fig. 7. Transport modes used for commuting in Benešov district Source: Pešek (2015), modified.

In terms of the size of the municipality (place of residence), there was no significant difference in the influence of the monitored factors on the choice of the means of transport. Nevertheless, with regard to the traffic position, the train was significantly preferred by respondents from town of Benešov and the surrounding municipalities (in combination with bus + train and car + train). A larger number of respondents from the town of Benešov, who have good train connections to Prague, have influenced the results of the chosen means of transport in favour of train transport.

Accessibility is a fundamental aspect in commuting and as Hudeček (2008) mentions, the distance is no longer a determining factor - it is how long the commute takes. More than four-fifths of the respondents $(83.1 \%)$ stated speed as one of the two factors in selecting the means of transport. The average commute time of the respondents to Prague is 61 minutes (driver without passengers - 42 minutes, train -67 minutes, bus - 77 minutes; Fig 8). The study also examined whether or not people would be willing to commute by 30 minutes longer to work. Almost three-fourths of the respondents $(72.9 \%)$ would not accept this, which means that the accessibility of Prague from the district of Benešov is the borderline for most respondents as far as the daily commute is concerned. 
In addition to the aforementioned basic characteristics of commuting, the intention of the questionnaire survey was to record the perception of the time of the commute; whether the commuters perceive the time spent on the way to work as pleasant, or wasted, suitable for rest, suitable for networking, or suitable for taking care of some work-related matters. The responses to the individual questions were tested for any statistically significant differences in perception between male and female, age categories, education, duration of the commute and selection of transport modes. Aside from two cases, no significant differences were recorded. There are only differences in the perception of suitability for networking while commuting to work in the different transport mode (drivers with passengers perceive it positively, unlike other respondents), and in the perception of the duration of the commute and its suitability for rest in the different means of transport (drivers do not perceive the time spent commuting as suitable for rest). The time of the commute suitable for rest was perceived most positively by commuters using a train $(76.2 \%)$ and also those commuting by bus $(60.0 \%)$. However, commuting by bus is also perceived negatively $(28.0 \%)$, whereas the negative opinions on the suitability of a train commute to rest were lower $(11.9 \%)$. When preparing the questionnaire, we also assumed that the commute could be suitable for networking. However, the majority of the respondents perceived the possibility of networking while commuting to work negatively $(67.8 \%)$, i.e., that the time spent commuting is not suitable for networking. Only the people who carpool have a significant positive response, where $43.3 \%$ perceive the time spent commuting to work as suitable for networking. With regard to pleasantness, people perceive the time of the commute mostly neutrally $(39.4 \%)$ and rather negatively (37.3\%). Only $23.3 \%$ of the respondents perceive the time of the commute positively. Most people perceive the time spent commuting to work as wasted $(50.0 \%)$ and $26.7 \%$ of the respondent perceive it neutrally. A number of respondents (37.7\%) perceive the time of the commute as suitable for taking care of some work-related matters, but a much larger number of respondents $(48.3 \%)$ do not have the same opinion. The response to this question would probably correspond with the job and job content; however, this aspect was not examined in the questionnaire survey.

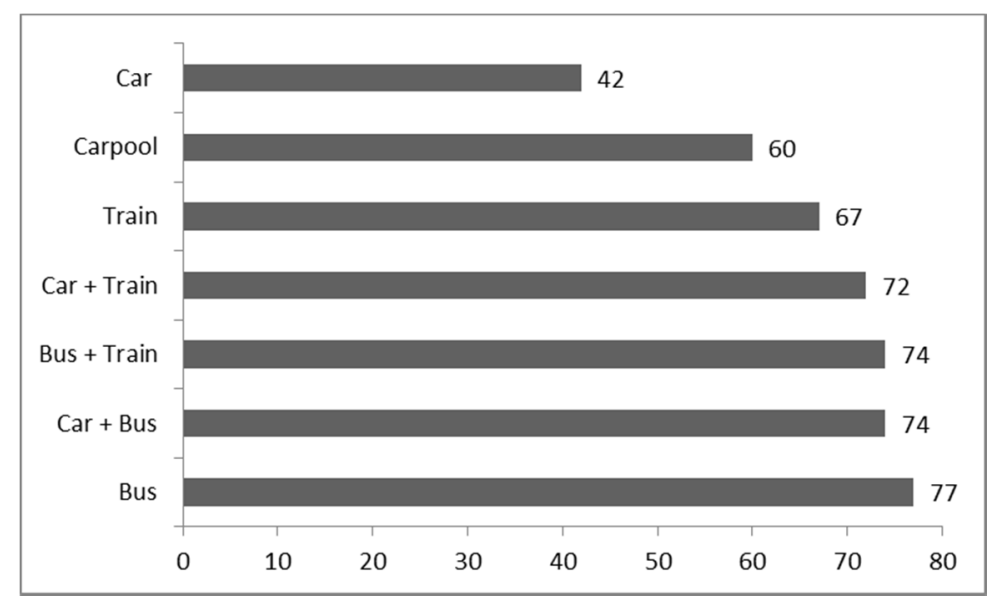

Fig. 8. Time spent by commuting according to used transport mode - one way average commuting time (min.)

Source: Pešek (2015), modified. 
With regard to the perception of time spent commuting to work, the respondents consider this time mostly wasted; with regard to pleasantness, they perceive it neutrally, or negatively. The respondents do not perceive the morning commute and transport mode as suitable for networking and they prefer to use the time for rest, and some use it for taking care of work-related matters. However, there are also differences based on the selected means of transport when public transport (mostly train) is perceived as more suitable for rest. When we compare the individual transport modes and their comparative advantages or disadvantages, then the advantages of the car are the speed and saved time, flexibility and comfort, with the disadvantages being the cost of transport and the potential issues with parking in Prague. The higher costs of transport can be solved by carpooling. On the other hand, the advantages of public transport include a lower price and the possibility to rest, while the disadvantages are limitations due to the schedule, longer commutes and worse accessibility and flexibility than in the case of the car.

The following part of the questionnaire survey focused on the perception of job opportunities in Prague and $91.2 \%$ of the respondents stated that jobs in Prague offer better pay conditions, they are more suitable for career growth $(84.8 \%$ of the respondents), and better for applying one's qualifications (83.9\% of the respondents). Thus, we can deduce that the respondents do not see any relevant job opportunities where they could build their career in the district of Benešov. The majority of the respondents $(79.2 \%)$ also perceive jobs in Prague as more suitable for networking and more prestigious than jobs in the region. The main reason for commuting is therefore better pay conditions and better job opportunities. The average monthly gross salary in the Czech Republic in mid-2017 according to the Czech Statistical Office was CZK 28,623 (EUR 1,118), whereas it was CZK 29,264 (EUR 1,143 ) in the Central Bohemian Region and CZK 36,642 (EUR 1,431) in Prague. This information completes the perception of the commute to a hierarchically higher and economically dominant centre. The economically active inhabitants are motivated to commute by the higher income as well as the overall attractiveness and accessibility to better job opportunities in the core area. In combination with the limited job opportunities in the wider hinterland (at the border of the microregional and inter-regional sphere of action) of the capital city of Prague and the convenient accessibility, a set of factors is created, influencing a lot of people and forcing them to commute to work from longer distances in many cases.

With regard to the time spent commuting and the monthly income, the study also examined the question as to whether it is possible to get an unambiguous answer to this question as $62.7 \%$ of the respondents replied to the purely theoretical question of whether or not they would accept a job within a 10-minute walking distance for a net monthly salary of CZK 15,000 (EUR 586) or a job that pays net CZK 17,500 (EUR 684) monthly with a 70-minute commute, then they would accept the job at the place of their residence (Fig. 9). However, when asked whether or not they would accept a similar job than they currently have in Prague at the place of their residence but with lower pay, most answers were negative. More than $70 \%$ of the respondents replied negatively in the case of a reduced regional pay of CZK 5,000 (EUR 195) that would only be lower by approx. CZK 2,000 (EUR 78) with the savings of the average cost of transport. 


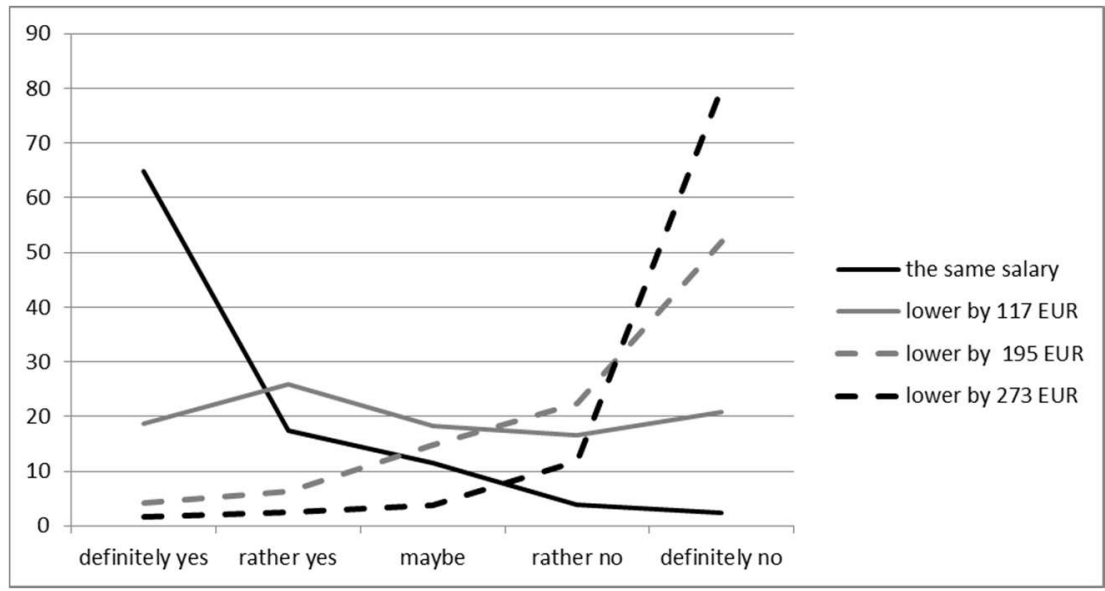

Fig. 9. Willingness to accept a lower salary for a shorter commuting Source: Pešek (2015), modified.

\section{CONCLUSIONS}

Spatial mobility and commuting to work has become an integral part of the lifestyle in the Czech Republic. The need to commute to work began to rise during the transformation period and it is still growing. And it is the increase in the need to commute to work that has a significant effect on the spatial organisation of the society - namely on the residential and regional structures and on the arrangements of the corresponding transport systems. The spatial changes induced by commuting in the monitored area are intense due to the proximity and attractiveness of the macro-regional centre of Prague to the district of Benešov, particularly in the north.

The tendencies in the development of spatial mobility and the related transport behaviour between 2001 and 2011 can be commented using the results of the case study concerning the exposed district of Benešov. Generally, integration processes are oriented from lower levels to the higher levels on the scale (similar to Hampl and Marada 2015) and this process is emphasised in the district of Benešov with the proximity of the capital city of Prague. $23 \%$ of the municipalities in the monitored region (approx. 20\% of the inhabitants of the district) redirected their primary catchment area from micro-regional centre to the macro-regional centre of Prague between 2001 and 2011. The effect of Prague's attractiveness has been manifested to such extent that it caused a significant reduction in the commuting integrity of the hinterland of the micro-regional centres of Benešov and Vlašim - most municipalities in these micro-regions have a secondary direction of commute directly to Prague. The town of Votice, which is an integral part of the organic micro-region of Benešov, even had a primary direction of commute to Prague in 2011, but it does not form a compact unit with the micro-regional hinterland of Prague and was thus left as a part of the micro-region of Benešov. Hampl and Marada (2015) write about how the centre - hinterland polarity gradually shifts from the micro-regional level to the inter-regional level and how the form of the centre changes from a nodal centre to an above-nodal level - a metropolitan area. This shift in the polarity of the hinterland to a higher hierarchical level in the district of Benešov is confirmed by the increased commute to work in Prague between 2001 and 2011 of 8.7 per- 
centage points - in 2011, 25.8\% of the total statistically recorded work commute in the district of Benešov goes to Prague. If the commute to the metropolitan area was also considered, then the effect of the metropolis on the Benešov region would increase even more because another $9.5 \%$ of the total work commuters in the district of Benešov commute to the districts of Prague-East and Prague-West. The destinations are centres in the immediate hinterland of Prague where there are mostly central warehouses of international companies, commercial zones and industrial production. The submitted results also imply the fact that the autonomous microregional centres are disappearing, especially in the metropolitan areas, due to their exposed positions. Within the context of development of regional relations in the monitored decade in the metropolitan area of Prague and further intensification of the relations inside this area, it can be expected that there will be a continued weakening of the sphere of action of the micro-regional centres of Benešov and Vlašim in the coming years.

The studied area of the district of Benešov is not affected by structural changes in the economy. The decision whether to commute to the metropolitan center is entirely individual and is influenced by the particular situation of the person. In particular, better pay conditions and better job opportunities with career growth are the motivation for commuting to work. In the event of a worsening economic situation in the region, the main reason for commuting to work could be the shortage of jobs in the place of residence. This would probably change the view of commuting and be seen more as a necessity to secure financial income. We also studied the willingness to accept a lower salary for a shorter commute, according to time spent by commuting and distance. The results clearly show the willingness to accept a lower salary is connected with a reduced commuting time. This willingness is of course limited by the lowering of the salary. This is an important issue in the relationship between commuting and its spatial scope. These results could help other researchers to conduct a research of the relationship between commuting time, income, spatial scope of commuting and willingness to work closer to residential areas.

This article is the output of the project called "New Mobility - High-Speed Transport Systems and Transport-Related Human Behaviour", Reg. No. CZ.02.1.01/0.0/0.0/16_026/0008430, co-financed by the "Operational Programme Research, Development and Education".

\section{REFERENCES}

ADEY, P. (2009). Mobility. London (Routledge).

BORÉN, T., GENTILE, M. (2007). Metropolitan processes in post-communist states: an introduction. Geografiska Annaler: Series B, Human Geography, 89, 95-110. DOI: 10.1111/j.1468-0467.2007.00242.x.

BURRELL, K., HÖRSCHELMANN, K. (2014). Mobilities in socialist and post-socialist states: societies on the move. (Palgrave Macmillan).

COHEN, S. A., GÖSSLING, S. (2015). A darker side of hypermobility. Environment and Planning A: Economy and Space, 47, 1660-1679.

CZSO (2002). Population and Housing Census 2001. Praha (Czech Statistical Office).

CZSO (2013). Population and Housing Census 2011. Praha (Czech Statistical Office).

FOTHERINGHAM, A. S. (1981). Spatial structure and distance-decay parameters. Annals of the Association of American Geographers, 71, 425-436. 
GRDZELISHVILI, I., SATHRE, R. (2011). Understanding the urban travel attitudes and behavior of Tbilisi residents. Transport Policy, 18, 38-45. DOI: 10.1016/ j.tranpol.2010.05.006.

HALÁS, M., KLAPKA, P., KLADIVO, P. (2014). Distance-decay functions for daily travel-to-work flows. Journal of Transport Geography, 335, 107-119. DOI: 10.1016/ j.jtrangeo.2014.02.001.

HAMPL, M. (2005). Geografická organizace společnosti v České republice: Transformační procesy a jejich obecný kontext. Praha (Univerzita Karlova v Praze).

HAMPL, M., MARADA, M. (2015). Sociogeografická regionalizace Česka. Geografie, $120,397-421$.

HANSON, S. (2004). The context of urban travel. In Hanson, S., Giuliano, G., eds. The geography of urban transportation, 3th ed. New York (Guilford Press), pp. 3-29.

HORNAK, M., PŠENKA, T. (2013). Verejná doprava ako indikátor medzisídelných väzieb madzi mestami Slovenska. Geografický časopis, 65, 119-140.

HUDEČEK, T. (2008). Akcesibilita a dopady její změny v Česku v transformačním obdobi: vztah k systému osídlení. Disertační práce. Př́rodovědecká fakulta, Univerzita Karlova, Praha.

HUDEČEK, T. (2010). Dostupnost v Česku v obdobi 1991-2001: vztah k dojižd'ce do zaměstnání a do škol. Česká geografická společnost. Praha (Česká geografická společnost).

KOMORNICKI, T. (2008). Changes of car ownership and daily mobility in selected Polish cities, Geografický časopis, 60, 339-362.

KRAFT, S., KVETON, T. (2015). Daily spatial mobility and transport behaviour in the Czech Republic - a case study of the Blatná region. Saarbrücken (Lambert Academic Publishing).

KRAFT, S., MARADA, M. (2017). Delimitation of functional transport regions: understanding the transport flows patterns at the micro-regional level. Geografiska Annaler: Series B, Human Geography, 99, 79-93. DOI: 10.1080/04353684.2017.1291741.

KRAFT, S., PRENER, J. (2014). Spatial aspects of transport behaviour in the Czech Republic after 1989. Acta Universitatis Palackianae Olomucensis, Facultas Rerum Naturalium, Geographica, 45(2), 53-77.

KRISJANE, Z., BERZINS, M., IVLEVS, A., BAULS, A. (2012). Who are the typical commuters in the post-socialist metropolis? The case of Riga, Latvia. Cities, 29, 334-340. DOI: $10.1016 /$ j.cities.2012.05.006.

MARADA, M., KVĚTON, V. (2016). Transport supply and demand changes in relation to unemployment: empirical evidence from the Czech Republic in a time of crisis. Tijdschrift voor Economische en Sociale Geografie, 107, 611-627. DOI: 10.1111/ tesg. 12186.

MARADA, M., KVĚTOŇ, V., VONDRÁČKOVÁ, P. (2010). Doprava a geografická organizace společnosti $v$ Česku. Praha (Česká geografická společnost).

MICHNIAK, D. (2015). Main problems of transport infrastructure development in Slovakia and effects on regional development. Geographia Polonica, 88, 21-39.

MUSIL, J., MÜLLER, J. (2008). Vnitřní periferie v České republice jako mechanismus sociální exkluze. Czech Sociological Review, 44, 321-348.

NOVÁK, J., SÝKORA, L. (2007). A city in motion: time-space activity and mobility patterns of suburban inhabitants and the structuration of the spatial organization of the Prague metropolitan area. Geografiska Annaler: Series B, Human Geography, 89, 147-168. DOI: $10.1111 / \mathrm{j} .1468-0467.2007 .00245 . \mathrm{x}$.

NOVOTNÝ, L. (2016). Urban development and migration processes in the urban region of Bratislava from the post-socialist transformation until the global economic crisis. Urban Geography, 37, 1009-1029. DOI: 10.1080/02723638.2016.1139413.

OUŘEDNIČEK, M. (2003). Suburbanizace Prahy. Czech Sociological Review, 39, 235253. 
OUŘEDNÍČEK, M. (2007). Differential suburban development in the Prague urban region. Geografiska Annaler: Series B, Human Geography, 89, 111-125. DOI: 10.1111/j.14680467.2007.00243.x.

PEŠEK, O. (2015). Sociogeografická regionalizace okresu Benešov v letech 2001-2011 a vliv pracovní atraktivity Prahy na její změny. Diplomová práca. Universita Karlova v Praze, Praha.

POPOV, V. (2012). The Cclture of new mobility in Russia: networks and flows formation. Mobilities, 7, 151-169. DOI: 10.1080/17450101.2012.631816.

PUCHER, J. (1990). Capitalism, socialism, and urban transportation policies and travel behaviour in the east and west. Journal of the A merican Planning Association, 56, 278296. DOI: 10.1080/01944369008975773.

PUCHER, J. (1999). The transformation of urban transport in the Czech Republic, 1988 1998. Transport Policy, 6, 255-236. DOI: 10.1016/S0967-070X(99)00023-2.

PUCHER, J., BUEHLER, R. (2005). Transport policy in post-communist Europe. Handbook of Transport Strategy, Policy and Institutions, 6, 725-743.

SCHWANEN, T., DIJST, M. (2002). Travel-time ratios for visits to the workplace: the relationship between commuting time and work duration. Transportation Research Part A: Policy and Practice, 36, 573-592. DOI: 10.1016/S0965-8564(01)00023-4.

SILM, S., AHAS, R., NUGA, M. (2013). Gender differences in space - time mobility patterns in a postcommunist city: a case study based on mobile positioning in the suburbs of Tallinn. Environment and Planning B Planning and Design, 40, 814-828. DOI: $10.1068 / \mathrm{b} 38068$.

SÝKORA, L., BOUZAROVSKI, S. (2012). Multiple transformations: Conceptualising the post-communist urban transition. Urban Studies, 49, 43-60. DOI: 10.1177/ 0042098010397402.

SÝKORA, L., MULÍČEK, O. (2009). The micro-regional nature of functional urban areas (FUAs): lessons from the analysis of Czech urban and regional system. Urban Research and Practice, 2, 287-307. DOI: 10.1080/17535060903319228.

ŠPAČKOVÁ, P., OUŘEDNÍČEK, M, FEŘTROVÁ, M. (2011). Změny sociálního prostředí a kvality života v depopulačních regionech České republiky. Czech Sociological Review, 47, 777-803.

ŠŤASTNÄ, M., VAISHAR, A., STONAWSKÁ, K. (2015). Integrated transport system of the south-Moravian region and its impact on rural development. Transportation Research Part D: Transport and Environment, 36, 53-64. DOI: 10.1016/j.trd. 2015.02.012.

TACZANOWSKI, J. (2012). A comparative study of local railway networks in Poland and the Czech Republic. Bulletin of Geography. Socio-economic Series, 18(18), 125-139.

TOMEŠ, Z., KVIZDA, M., NIGRIN, T., SEIDENGLANZ, D. (2014). Competition in the railway passenger market in the Czech Republic. Research in Transportation Economics, 48, 270-276. DOI: 10.1016/j.retrec.2014.09.052.

TONEV, P. (2013). Změny v dojižd'ce za prací v období transformace: komparace lokálních trhù práce. Disertační práce. Př́írodovědecká fakulta, Masarykova univerzita, Brno.

ZELINSKY, W. (1971). The hypothesis of the mobility transition. Geographical Review, $61,219-249$.

Ondřej P e š e k, Stanislav Kraft

\section{PROSTOROVÁ MOBILITA A SOUČASNÉ DOPRAVNÍ CHOVÁNÍ V ZÁZEMÍ METROPOLITNÍHO REGIONU}

Prostorová mobilita, a zejména pak dojížd'ka za prací, se stala nedílnou součástí každodenního života. V Česku se trend nárůstu potřeby dojiždět za prací začal projevovat v transformačním období a pokračuje stále i do současnosti. A právě nárůst dojížd’ky za prací má 
značný vliv na prostorovou organizaci společnosti - zejména na sídelní a regionální struktury a uspořádání příslušných dopravních systémů. Specificky se projevuje nárůst dojižd'ky obyvatel na větší vzdálenosti v metropolitních regionech. Vlivem blízkosti a atraktivity makroregionálního centra Prahy vůči okresu Benešov jsou tyto prostorové změny vyvolané dojížd'kou ve sledovaném území intenzivní, a to zejména v jeho severní části.

Vývojové tendence sociogeografického uspořádání Česka dlouhodobě sleduje Hampl a v kontextu jeho hodnocení vývoje mezi roky 2001 - 2011 (Hampl a Marada 2015) lze komentovat výsledky výzkumu na př́ípadové studii exponovaného okresu Benešov. Všeobecně dochází $\mathrm{k}$ orientaci integračních procesů od měřítkově nižších úrovní $\mathrm{k}$ úrovním měřítkově vyšším (Hampl a Marada 2015) a v okrese Benešov je tento proces umocněn blízkostí hlavního města Prahy. U $23 \%$ obcí sledovaného okresu (cca $20 \%$ obyvatel okresu) došlo mezi roky 2001 - 2011 k přeorientování jejich primární spádovosti z mikroregionálních center na makroregionální centrum Praha. Svou dojížd’kovou orientaci v tomto období změnil i mikroregion Vlašim, který $\mathrm{v}$ roce 2001 spadal pod mikroregion Benešov, ale v roce 2011 již spadá pod př́mý vliv hlavního města Prahy. Vliv atraktivity Prahy se projevil natolik, že došlo během deseti let k výraznému poklesu pracovní spjatosti a integrit zázemí mikroregionálních center Benešov a Vlašim - většina obcí v těchto mikroregionech má sekundární směr vyjížd'ky přímo na Prahu.

Uvedené změny byly doloženy analýzou dat ze Sčítání lidu, domů a bytů z let 2001 a 2011. Na to pak navazoval výzkum dopravního chování obyvatel okresu Benešov formou dotazníkového šetření. Výsledky výzkumu jednoznačně prokázaly větší př́ílon lidí k využívání osobního automobilu, který je však v některých případech sycen větším prostorově selektivním využíváním veřejné dopravy, př́ípadně kombinace veřejné a individuální dopravy. Za hlavní konkurenční výhodu osobního automobilu respondenti považují zejména časovou a prostorovou flexibilitu tohoto dopravního módu. V poslední části výzkumu respondenti deklarovali, že by byli ochotni změnit místo svého pracoviště lokalizované v Praze do bližšího pracovního centra pouze v př́padě zachování stávajícího platu, resp. při mírném snížení. Naopak výraznější snížení platu za cenu kratšího dojíždění za prací by preferovala pouze omezená část respondentů. 
